\title{
TINGKAT PERSEPSI KONSUMEN DALAM KEPUTUSAN PEMBELIAN BUAH PEPAYA CALIFORNIA DI PASAR SWALAYAN
} ( Studi Kasus di Toserba Yogya Ciamis)

\author{
Oleh : \\ Sulistiani Mardiah $^{1}$, Soetoro ${ }^{2}$, Sudradjat ${ }^{3}$ \\ ${ }^{13}$ Fakultas Pertanian Universitas Galuh \\ ${ }^{2}$ Fakultas Pertanian Universitas Padjadjaran
}

\begin{abstract}
Abstrak
Penelitian ini bertujuan untuk mengetahui : (1) Tingkat persepsi konsumen dalam keputusan pembelian buah pepaya california di pasar swalayan (2) Kendala yang dihadapi dalam kegiatan pengambilan keputusan pembelian buah pepaya california. Penelitian ini menggunakan pendekatan kualitatif dengan metode studi kasus. Teknik penarikan sampel menggunakan Non-probability sampling dengan cara judgement sampling pada 30 orang konsumen buah pepaya california di Toserba Yogya Ciamis. Hasil penelitian menunjukkan bahwa : 1) Tingkat persepsi konsumen dalam keputusan pembelian buah pepaya california di pasar swalayan yang dilakukan di Toserba Yogya Ciamis tergolong ke dalam kategori sedang. Tingkat persepsi jika dilihat per dimensi yaitu : a) Dimensi produk memiliki tingkat persepsi baik. b) Dimensi harga memiliki tingkat persepsi sedang. c) Dimensi promosi memiliki tingkat persepsi sedang. 2) Kendala yang dihadapi dalam melakukan kegiatan pengambilan keputusan pembelian pepaya california di pasar swalayan yaitu : a) Kendala internal ; pengalaman belajar dan memori dalam membeli buah pepaya california, dimana dimensi harga menjadi kendala. Selain itu kepribadian dan konsep diri, beberapa responden memiliki konsep dalam membeli buah pepaya california. Yang penting memiliki rasa buah pepaya california yang sama, responden tak perlu lagi membeli di pasar swalayan . b) Kendala Eksternal ; faktor sosial yaitu kelompok referensi dan keluarga, perolehan informasi dan referensi tempat lain.
\end{abstract}

\section{PENDAHULUAN}

Seiring dengan semakin ketatnya persaingan antar negara, sektor pertanian dituntut agar dapat memacu pusat-pusat pertumbuhan baru yang dapat memberikan pengaruh yang signifikan terhadap pembangunan ekonomi nasional. Salah satu pusat pertumbuhan baru yang sangat potensial dikembangkan pada masa kini dan masa depan adalah sub sektor hortikultura (Azhari, 2004).

Menurut Suryani (2010) dalam Trimastuty, Kusnandar dan Utami (2013), salah satu komoditas agribisnis hortikultura yang memiliki potensi besar untuk dikembangkan adalah pepaya. Menurut Sobir (2010) dalam Susanti, Ratini dan Mariyah (2014), pepaya (Carica papaya L.) merupakan komoditas buah trika utama. Sering dinamakan sebagai the healt of the angels, karena rasanya dikatakan sebagai rasa surga dan sangat bermanfaat untuk kesehatan.

Salah satu jenis pepaya yang saat ini digemari petani karena menjanjikan keuntungan adalah pepaya california. Menurut Gita (2005), bahwa pepaya california merupakan jenis pepaya eksotik yaitu varietas baru yang memiliki keunggulan tersendiri, rasanya lebih manis, bisa dipanen lebih cepat, ukurannya tidak terlalu besar, kulitnya halus dan mengkilap.

Peluang pemasaran pepaya california yaitu pasar swalayan, supermarket dan outlet khusus yang merupakan pasar modern yang menjual buahbuahan segar, dimana konsumen kelas menengah ke atas sebagai pasar sasaran yang akan dituju.

Di Kabupaten Ciamis terdapat beberapa pasar, salah satunya pasar modern seperti swalayan dan minimarket, dimana sebagian masyarakat lebih memilih memenuhi kebutuhan rumah tangganya dari pasar swalayan dengan alasan kenyamanan, produk yang tersedia lebih bervariasi dan lebih praktis serta dapat meningkatkan prestise atau image. Walaupun harga yang dijual di pasar swalayan cenderung lebih mahal, tetapi dengan adanya suatu prestise dan kenyamanan dapat menciptakan kepuasan tersendiri untuk masyarakat pada saat membeli buah pepaya california.

Toserba Yogya merupakan toserba atau swalayan terbesar di Kabupaten Ciamis yang menyediakan buah pepaya california, sehingga banyak konsumen yang bisa dijadikan responden dalam penelitian ini .

\section{METODE PENELITIAN \\ Jenis Penelitian}

Jenis penelitian yang digunakan yaitu pendekatan penelitian kualitatif dengan metode studi kasus. Menurut Nazir (2011), studi kasus merupakan suatu penelitian yang bersifat mendalam mengenai suatu karakteristik tertentu dari objek penelitian. 


\section{Operasionalisasi Variabel}

Untuk mempermudah dan memperjelas penafsiran dalam membahas permasalahan penelitian ini, maka variabel-variabel yang diteliti dioperasionalisasikan sebagai berikut :

1) Persepsi konsumen adalah perilaku konsumen dalam membuat keputusan membelanjakan sumber daya yang tersedia dan dimiliki (waktu, uang dan usaha) untuk mendapatkan barang atau jasa yang nantinya akan dikonsumsi. Penilaian dengan sistem skoring.

2) Dimensi Persepsi Konsumen adalah 3 macam segi, yaitu segi produk, segi harga dan segi promosi dalam pengambilan keputusan pembelian.

3) Faktor produk adalah suatu hal yang ditawarkan kepada konsumen yaitu pepaya california.

(a) Warna buah pepaya california adalah baik atau tidaknya warna kulit buah pepaya california dinilai dari persepsi konsumen saat membelinya di Toserba Yogya Ciamis. Penilaian dengan sistem skoring.

(b) Rasa buah pepaya california adalah memiliki rasa yang baik atau tidaknya dinilai berdasarkan persepsi konsumen saat membeli di Toserba Yogya Ciamis. Penilaian dengan sistem skoring.

(c) Kesegaran buah pepaya california adalah segar atau tidaknya buah pepaya berdasarkan penilaian persepsi dari konsumen. Penilaian dengan sistem skoring.

(d) Kandungan gizi buah pepaya california adalah baik, sedang atau buruk dinilai persepsi konsumen saat membeli di Toserba Yogya Ciamis. Penilaian dengan sistem skoring.

(e) Kebersihan buah pepaya california adalah bersih atau tidaknya buah pepaya california berdasarkan pandangan atau persepsi konsumen saat membelinya di Toserba Yogya Ciamis. Penilaian dengan sistem skoring.

4) Faktor harga adalah sejumlah uang untuk mendapatkan pepaya california (produk ) dan pelayanannya.

(a) Kesesuaian harga buah pepaya california adalah kesesuaian harga yang dinilai, baik, sedang atau buruk tergantung persepsi konsumen saat membelinya di Toserba Yogya Ciamis. Penilaian dengan sistem skoring.

(b) Tingkat harga buah pepaya california adalah sesuai atau tidaknya tingkat harga yang ditawarkan berdasarkan persepsi konsumen saat membelinya. Penilaian dengan sistem skoring.

(c) Keterjangkauan harga buah pepaya california adalah buah pepaya california dikatakan terjangkau atau tidaknya tergantung persepsi konsumen saat membelinya di Toserba Yogya Ciamis. Penilaian dengan sistem skoring.

(d) Potongan harga buah pepaya California adalah penilaian akan potongan harga saat membeli buah pepaya california di Toserba Yogya Ciamis tergantung persepsi dan pengalaman yang pernah dirasakan konsumen. Penilaian dengan sistem skoring.

5) Faktor promosi adalah aktivitas pengiklanan atau pengenalan produk kepada konsumen.

(a) Iklan buah pepaya california adalah indikator untuk menyampaikan promosi pepaya california kepada pembeli, baik atau tidaknya iklan buah pepaya california yang dilakukan Toserba Yogya Ciamis berdasarkan penilaian persepsi konsumen sebelum atau bahkan saat membeli buah pepaya california. Penilaian dengan sistem skoring.

(b) Ketersediaan buah pepaya california adalah tersedia atau tidaknya buah pepaya california di Toserba Yogya Ciamis dinilai berdasarkan persepsi konsumen saat membeli. Penilaian dengan sistem skoring.

(c) Personal Selling (tenaga penjualan/wiraniaga) adalah baik atau tidaknya pelayanan dari wiraniaga/ tenaga penjualan di Toserba Yogya dinilai berdasarkan persepsi konsumen saat membeli. Penilaian dengan sistem skoring.

6) Keputusan pembelian adalah tahap pemilihan dalam menentukan pembelian buah pepaya california.

\section{Teknik Pengumpulan Data}

Jenis data yang digunakan meliputi data primer dan data sekunder . Data primer adalah data yang diperoleh berdasarkan pengamatan langsung di lapangan dengan melalui wawancara dengan pembeli pepaya california di pasar swalayan. Data sekunder adalah data yang diperoleh dari lembaga terkait dan bahan-bahan kepustakaan, internet yang terkait yang relevan.

\section{Teknik Penarikan Sampel}

Penelitian ini dilakukan dengan metode Nonprobability sampling dengan cara judgement sampling pada Toserba Yogya Ciamis. Ukuran sampel pada penelitian ini menggunakan pendapat Roscoe dalam Sugiyono (2012), yang menyatakan bahwa ukuran sampel lebih dari 30 dan kurang dari 
500 adalah tepat untuk kebanyakan penelitian, dimana sampel dipecah ke dalam sub sampel (pria/wanita, dsb) ukuran sampel minimum 30 untuk tiap kategori adalah tepat. Maka dari itu untuk pengambilan sampel, penulis mengambil batas terendah untuk mewakili yaitu 30 orang.

\section{Rancangan Analisis Data}

Analisis data yang digunakan dalam penelitian ini yaitu analisis deskriptif dengan mencari interval. Namun sebelum menentukan panjang kelas interval, data diolah dalam bentuk persentase pada tabel frekuensi distribusi, dengan menggunakan rumus menurut Singarimbun dan Efendy (1995) dalam Saharuddin (2012) :

$$
\mathrm{P}=\frac{f}{n} \times 100 \%
$$

Keterangan :

$\mathrm{P}=$ Persentase

$\mathrm{f}=$ Frekuensi

$\mathrm{n}=$ Jumlah responden

Kemudian tingkat persepsi konsumen dalam keputusan pembelian buah pepaya california di pasar swalayan dibagi dalam 3 kategori. Rumus yang digunakan menurut Akdon dan Riduwan (2001) sebagai berikut :

$$
\mathrm{P}=\frac{\text { Rentang }}{\text { Banyak Kelas Interval }}
$$

Atau :

Rentang $=\left(\mathrm{N}_{\max }-\mathrm{N}_{\min }\right)$

Keterangan :

$\mathrm{N}_{\max }=$ Nilai Maksimal dari masing-masing variabel dan indikatornya.

$\mathrm{N}_{\min }=$ Nilai Minimal dari masing-masing variabel dan indikatornya.

Dari rumus di atas dapat ditentukan interval masing-masing kategori, yaitu sebagai berikut :

a) Tingkat persepsi rendah $=12 \leq \mathrm{Q}<20$

b) Tingkat persepsi sedang $=20 \leq \mathrm{Q}<28$

c) Tingkat persepsi tinggi $=28 \leq \mathrm{Q} \leq 36$

Dimana $Q$ adalah Nilai yang dicapai.

Untuk mengetahui kendala yang dihadapi konsumen dalam mengambil keputusan pembelian buah pepaya california dilakukan analisis deskriptif.

\section{Waktu dan Tempat Penelitian}

Penelitian ini dilaksanakan di Toserba Yogya Ciamis. Adapun waktu yang digunakan untuk melakukan penelitian ini yaitu mulai bulan Februari sampai dengan selesai melalui beberapa tahapan sebagai berikut:

1) Tahapan persiapan yaitu survai pendahuluan, penulisan usulan penelitian dan seminar usulan penelitian dilaksanakan bulan Februari sampai dengan Maret 2016.
2) Tahap pengumpulan data dari lapangan pada bulan April 2016

3) Tahap pengolahan data, penyusunan dan penulisan skripsi dilaksanakan pada bulan Mei 2016 sampai dengan selesai.

\section{HASIL DAN PEMBAHASAN}

\section{A. Gambaran Umum Responden}

Berdasarkan hasil penelitian kepada 30 orang responden diperoleh gambaran karakteristik responden meliputi umur, jenis kelamin, pendidikan terakhir, pekerjaan dan jumlah penghasilan dalam 1 bulan.

\section{Umur Responden}

Umur responden konsumen buah pepaya california di Toseba Yogya Ciamis bervariasi antara 24 - 65 tahun. Umur responden berdasarkan kelompok umur dapat dilihat pada Tabel 1.

Tabel 1. Keadaan Responden Berdasarkan Kelompok Umur

\begin{tabular}{|c|c|c|c|}
\hline \multirow{2}{*}{ No } & \multirow{2}{*}{$\begin{array}{c}\text { Kelompok } \\
\text { Umur } \\
\text { (Tahun) }\end{array}$} & \multicolumn{2}{|c|}{ Jumlah } \\
\cline { 3 - 4 } & $15-64$ & Orang & $\begin{array}{c}\text { Persentase } \\
\text { (\%) }\end{array}$ \\
\hline 1. & $>64$ & 28 & 93,33 \\
\hline 2. & $>64$ & 6,67 \\
\hline \multicolumn{2}{|c|}{ Jumlah } & $\mathbf{3 0}$ & $\mathbf{1 0 0 , 0 0}$ \\
\hline
\end{tabular}

Berdasarkan Tabel 1 diketahui bahwa sebagian besar responden yaitu sebanyak 28 orang $(93,33$ $\%)$ termasuk ke dalam usia produktif dimana usia produktif berkisar antara $15-64$ tahun. Hal tersebut memungkinkan responden memiliki persepsi atau pandangan sendiri akan keputusan pembelian buah pepaya california.

\section{Jenis Kelamin}

Karakteristik responden berdasarkan jenis kelamin, selengkapnya disajikan pada Tabel 2.

\section{Tabel 2. Jenis Kelamin Responden}

\begin{tabular}{|c|c|c|c|}
\hline No & $\begin{array}{c}\text { Jenis Kelamin } \\
\text { Responden }\end{array}$ & $\begin{array}{c}\text { Jumlah } \\
\text { Responden } \\
\text { ( orang ) }\end{array}$ & $\begin{array}{c}\text { Persentase } \\
(\%)\end{array}$ \\
\hline 1 & Laki-laki & 4 & 13,33 \\
\hline 2 & Perempuan & 26 & 86,67 \\
\hline & Total & 30 & 100,00 \\
\hline
\end{tabular}

Tabel 2 menunjukkan bahwa responden lakilaki sebanyak 4 orang $(13,33 \%)$ dan responden perempuan sebanyak 26 orang $(86,67 \%)$. Dari data di atas dapat disimpulkan bahwa dalam pengambilan keputusan pembelian buah pepaya 
california perempuan lebih mendominasi dibanding laki-laki.

\section{Pendidikan Responden}

Pendidikan responden bervariasi mulai dari tamat Sekolah Menengah Pertama (SMP) sampai Tabel 3. Tingkat Pendidikan Responden

\begin{tabular}{|c|c|c|c|}
\hline No & $\begin{array}{c}\text { Tingkat } \\
\text { Pendidikan }\end{array}$ & $\begin{array}{c}\text { Jumlah } \\
\text { Responden } \\
\text { ( Orang) }\end{array}$ & $\begin{array}{c}\text { Persentase } \\
(\%)\end{array}$ \\
\hline 1. & Tamat SMP & 1 & 3,33 \\
\hline 2. & Tamat SMA & 17 & 56,67 \\
\hline 3. & Perguruan Tinggi & 12 & 40,00 \\
\hline & Jumlah & 30 & 100,00 \\
\hline
\end{tabular}

Tabel 3 menunjukkan, tingkat pendidikan responden sebagian besar tamat SMA yaitu sebanyak 17 orang $(56,67 \%)$ dan kemudian lulusan perguruan tinggi sebanyak 12 orang (40,00\%), serta yang tamat SMP hanya 1 orang $(3,33 \%)$.

\section{Pekerjaan Responden}

Perguruan Tinggi. Keadaan responden berdasarkan pendidikan dapat dilihat pada Tabel 3.

Data pekerjaan responden dapat dilihat pada Tabel 4.

Tabel 4. Pekerjaan Responden

\begin{tabular}{|c|c|c|c|}
\hline No & Pekerjaan & $\begin{array}{c}\text { Jumlah } \\
\text { Responden } \\
\text { ( Orang) }\end{array}$ & $\begin{array}{c}\text { Persentase } \\
(\%)\end{array}$ \\
\hline 1 & Ibu Rumah Tangga & 4 & 13,33 \\
\hline 2. & Karyawan Swasta & 17 & 56,67 \\
\hline \multirow[t]{2}{*}{3.} & PNS & 9 & 30,00 \\
\hline & Jumlah & 30 & 100,00 \\
\hline
\end{tabular}

Tabel 4 menunjukkan bahwa sebagian besar dari responden memiliki pekerjaan sebagai karyawan swasta yaitu sebanyak 17 orang $(56,67$ $\%$ ) dari seluruh responden yang diteliti

\section{Penghasilan Responden Rata-Rata Per Bulan}

Selain pekerjaan, tentu penghasilan menjadi hal yang berpengaruh pada stimulus konsumen sehingga memiliki persepsi dan memiliki keinginan untuk melihat hingga akhirnya membeli. Di bawah ini data penghasilan responden yang disajikan pada Tabel 5.

Tabel 5. Penghasilan Responden Per Bulan

\begin{tabular}{|c|c|c|c|}
\hline No & Penghasilan Per Bulan & $\begin{array}{l}\text { Jumlah Responden } \\
\text { ( Orang) }\end{array}$ & $\begin{array}{l}\text { Persentase } \\
\quad(\%)\end{array}$ \\
\hline 1 & $<$ Rp. 500.000 & - & - \\
\hline 2. & Rp. $500.000 \leq$ Q $<$ Rp. 2.000 .000 & 8 & 26,67 \\
\hline 3. & Rp. 2.000.000 $\leq \mathrm{Q}<$ Rp. 3.500 .000 & 9 & 30,00 \\
\hline \multirow[t]{2}{*}{4.} & $>$ Rp. 3.500 .000 & 13 & 43,33 \\
\hline & Jumlah & 30 & 100,00 \\
\hline
\end{tabular}

Tabel 5 menunjukkan, bahwa dari 30 orang responden sebanyak 13 orang $(43,33 \%)$ memiliki penghasilan > Rp. 3.500.000. Hal tersebut mengindikasikan semakin tinggi penghasilan semakin tinggi pula kebutuhannya termasuk kebutuhan sekunder atau tersier.

\section{B. Tingkat Persepsi Dalam Keputusan Pembelian Buah Pepaya California}

Tingkat persepsi dalam keputusan pembelian buah pepaya california di pasar swalayan dinyatakan berdasarkan skor. Kriteria yang digunakan untuk mengetahui tingkat persepsi konsumen pada keputusan pembelian buah pepaya california dibagi dalam tiga kategori yaitu : 1) baik, 2) sedang dan 3) buruk. Namun sebelum menyajikan hasil perhitungan tingkat persepsi konsumen, penulis menyajikan persentase frekuensi distribusi hasil pengisian kuesioner dari 30 orang responden dalam Tabel 6. 
Tabel 6. Persentase Frekuesi Distribusi Hasil Pengisian Kuesioner Dalam Menilai Persepsi Konsumen Dalam Keputusan Pembelian Buah Pepaya Caliornia di Pasar Swalayan $(\mathbf{n}=\mathbf{3 0})$

\begin{tabular}{|c|c|c|c|c|}
\hline \multirow{2}{*}{ No } & \multirow{2}{*}{ Pertanyaan } & \multicolumn{3}{|c|}{ Persepsi } \\
\hline & & Buruk & Sedang & Baik \\
\hline \multirow[t]{13}{*}{1.} & Dimensi Produk (Buah Pepaya California) & & & \\
\hline & 1.Warna kulit & 0 & 17 & 13 \\
\hline & & 0 & $56,70 \%$ & $43,30 \%$ \\
\hline & 2. Rasa & 0 & 0 & 30 \\
\hline & & 0 & 0 & $100 \%$ \\
\hline & 3. Kesegaran & 0 & 23 & 7 \\
\hline & & 0 & $76,70 \%$ & $23,30 \%$ \\
\hline & 4. Kandungan Gizi & 0 & 0 & 30 \\
\hline & & 0 & 0 & $100 \%$ \\
\hline & 5.Kebersihan kulit & 0 & 19 & 11 \\
\hline & & 0 & $63,30 \%$ & $36,70 \%$ \\
\hline & Rata-rata & 0 & 12 & 18 \\
\hline & & 0 & $40 \%$ & $60 \%$ \\
\hline \multirow[t]{11}{*}{2.} & Dimensi Harga & & & \\
\hline & 1. Kesesuian harga & 5 & 15 & 10 \\
\hline & & $16,70 \%$ & $50 \%$ & $33,30 \%$ \\
\hline & 2. Tingkat Harga & 0 & 24 & 6 \\
\hline & & 0 & $80 \%$ & $20 \%$ \\
\hline & 3. Keterjangkauan harga & 0 & 20 & 10 \\
\hline & & 0 & $66,70 \%$ & $33,30 \%$ \\
\hline & 4.Potongan harga & 23 & 7 & 0 \\
\hline & & $76,70 \%$ & $23,30 \%$ & 0 \\
\hline & Rata-rata & 7 & 17 & 6 \\
\hline & & $23,30 \%$ & $56,70 \%$ & $20 \%$ \\
\hline \multirow[t]{9}{*}{3.} & Dimensi Promosi & & & \\
\hline & 1.Iklan & 19 & 11 & 0 \\
\hline & & $63,30 \%$ & $36,70 \%$ & 0 \\
\hline & 2. Ketersediaan & 0 & 20 & 10 \\
\hline & & 0 & $66,70 \%$ & $33,30 \%$ \\
\hline & 3.Personal selling (pelayanan) & 0 & 14 & 16 \\
\hline & & 0 & $46,70 \%$ & $53,30 \%$ \\
\hline & Rata-rata & 6 & 15 & 9 \\
\hline & & $20 \%$ & $50 \%$ & $30 \%$ \\
\hline
\end{tabular}

Dari Tabel 6 diketahui bahwa persentase persepsi rata-rata per dimensi tertinggi yaitu $60 \%$ pada dimensi produk. Hal ini dapat disimpulkan bahwa produk buah pepaya california di Toserba Yogya Ciamis memang memiliki persepsi baik menurut anggapan konsumen. Namun pada dimensi harga dan promosi persepsi konsumen hanya masuk kategori sedang karena pada indikator tertentu seperti potongan harga dan iklan, konsumen menganggap hal tersebut masuk kategori buruk, persentasenya yaitu $76,70 \%$ untuk indikator potongan harga dan $63,30 \%$ untuk indikator iklan.

Setelah disajikan dalam bentuk persentase frekuensi distribusi, selanjutnya untuk mengetahui tingkat persepsi konsumen dalam keputusan pembelian buah pepaya california di pasar swalayan, peneliti menyajikannya dalam bentuk interval yang dibagi 3 kategori seperti dapat dilihat pada Tabel 7.

Tabel 7. Tingkat Persepsi Konsumen Pada Keputusan Pembelian Buah Pepaya California di Pasar Swalayan (Toserba Yogya Ciamis)

\begin{tabular}{|c|c|c|c|c|}
\hline $\begin{array}{c}\mathbf{N} \\
\mathbf{0}\end{array}$ & Nilai skor & $\begin{array}{c}\text { Jumlah } \\
(\text { Orang) }\end{array}$ & $\begin{array}{c}\text { Kategori } \\
\text { Penilaian }\end{array}$ & $\begin{array}{c}\text { Persentase } \\
(\mathbf{\%})\end{array}$ \\
\hline $\mathbf{1}$ & $12 \leq \mathrm{Q}<20$ & - & Buruk & - \\
\hline $\mathbf{2}$ & $21 \leq \mathrm{Q}<28$ & 22 & Sedang & 73,33 \\
\hline $\mathbf{3}$ & $29 \leq \mathrm{Q} \leq 36$ & 8 & Baik & 26,67 \\
\hline \multicolumn{2}{|l|}{ Jumlah } & $\mathbf{3 0}$ & & $\mathbf{1 0 0 , 0 0}$ \\
\hline
\end{tabular}

Tabel 7 menunjukkan bahwa, dari 30 orang responden yang diteliti, secara umum dalam 
pengambilan keputusan pembelian buah pepaya california memiliki tingkat persepsi konsumen sedang. Hal tersebut dapat di lihat bahwa tidak ada seorang pun yang memiliki persepsi buruk namun sebanyak 22 orang responden atau sebanyak 73,33 $\%$ memiliki persepsi sedang dan 8 orang responden atau sebanyak 26,67 \% memiliki persepsi baik. Ini memiliki arti, konsumen memiliki persepsi yang tidak terlalu buruk pada pembelian buah pepaya california namun juga tidak terlalu baik.

\section{Tingkat Persepsi Konsumen Pada Dimensi \\ Produk}

Dimensi produk adalah hal pertama yang merangsang stimulus persepsi visual pada konsumen untuk melakukan keputusan pembelian . Dalam penelitian ini produk dimaksud adalah hal yang berupa fisik luar dari buah pepaya california. Persepsi atau pandangan akan fisik buah pepaya california disajikan pada Tabel 8 .

\section{Tabel 8. Tingkat Persepsi Konsumen Pada Dimensi Produk}

\begin{tabular}{|l|c|c|c|c|}
\hline $\begin{array}{l}\mathbf{N} \\
\mathbf{0}\end{array}$ & Nilai skor & $\begin{array}{c}\text { Jumlah } \\
(\text { Orang) }\end{array}$ & $\begin{array}{c}\text { Kategori } \\
\text { Penilaian }\end{array}$ & $\begin{array}{c}\text { Persentase } \\
(\mathbf{\%})\end{array}$ \\
\hline $\mathbf{1}$ & $5 \leq \mathrm{Q} \leq 8,33$ & - & Buruk & - \\
\hline $\mathbf{2}$ & $8,33 \leq \mathrm{Q} \leq 11,66$ & - & Sedang & - \\
\hline $\mathbf{3}$ & $11,66 \leq \mathrm{Q} \leq 15$ & 30 & Baik & 100,00 \\
\hline \multicolumn{2}{|l}{ Jumlah } & $\mathbf{3 0}$ & & $\mathbf{1 0 0 , 0 0}$ \\
\hline
\end{tabular}

Dari Tabel 8 diketahui bahwa tingkat persepsi konsumen akan produk buah pepaya california yang disediakan Toserba Yogya Ciamis memiliki persepsi baik menurut konsumen. Karena konsumen memiliki pandangan produk yang tersedia memang berkualitas baik.

\section{Tingkat Persepsi Pada Dimensi Harga}

Dimensi harga adalah hal yang selanjutnya menjadi stimulus pada konsumen. Setelah persepsi visual kemungkinan lainnya adalah persepsi pengecapan dimana ada kemungkinan konsumen ingin mencoba buah pepaya california yang disediakan Toserba Yogya. Selengkapnya tingkat persepsi pada dimensi harga disajikan pada Tabel 9.

Tabel 9. Tingkat Persepsi Konsumen Berdasarkan Dimensi Harga

\begin{tabular}{|c|c|c|c|c|}
\hline $\begin{array}{l}\mathbf{N} \\
\mathbf{0}\end{array}$ & Nilai skor & $\begin{array}{c}\text { Jumlah } \\
\text { (Orang) }\end{array}$ & $\begin{array}{c}\text { Kategori } \\
\text { Penilaian }\end{array}$ & $\begin{array}{c}\text { Persentase } \\
(\mathbf{\%})\end{array}$ \\
\hline $\mathbf{1}$ & $4 \leq \mathrm{Q} \leq 6,7$ & 3 & Buruk & 10,00 \\
\hline $\mathbf{2}$ & $6,7 \leq \mathrm{Q} \leq 9,4$ & 25 & Sedang & 83,33 \\
\hline $\mathbf{3}$ & $9,4 \leq \mathrm{Q} \leq 12$ & 2 & Baik & 6,67 \\
\hline \multicolumn{2}{|l}{ Jumlah } & $\mathbf{3 0}$ & & $\mathbf{1 0 0 , 0 0}$ \\
\hline
\end{tabular}

\section{Tingkat Persepsi Pada Dimensi Promosi}

Dimensi promosi merupakan hal penting, dalam hal ini konsumen perlu mengetahui produk dan harga melalui promosi baik berupa informasi dari berbagai media atau pun personal selling. Tingkat persepsi konsumen pada dimensi promosi disajikan pada Tabel 10.

\section{Tabel 10. Tingkat Persepsi Pada Dimensi Promosi}

\begin{tabular}{|c|c|c|c|c|}
\hline $\begin{array}{l}\text { N } \\
\mathbf{0}\end{array}$ & Nilai skor & $\begin{array}{c}\text { Jumlah } \\
\text { (Orang) }\end{array}$ & $\begin{array}{c}\text { Kategori } \\
\text { Penilaian }\end{array}$ & $\begin{array}{c}\text { Persentase } \\
(\boldsymbol{\%})\end{array}$ \\
\hline $\mathbf{1}$ & $3 \leq \mathrm{Q} \leq 5$ & 6 & Buruk & 20,00 \\
\hline $\mathbf{2}$ & $5 \leq \mathrm{Q} \leq 7$ & 23 & Sedang & 76,67 \\
\hline $\mathbf{3}$ & $7 \leq \mathrm{Q} \leq 9$ & 1 & Baik & 3,33 \\
\hline \multicolumn{2}{|c|}{ Jumlah } & $\mathbf{3 0}$ & & $\mathbf{1 0 0 , 0 0}$ \\
\hline
\end{tabular}

\section{Kendala dalam Pengambilan Keputusan Pembelian Buah Pepaya California Di Toserba Yogya Ciamis}

\section{a) Kendala Internal}

Kendala yang dihadapi responden dalam pengambilan keputusan pembelian buah pepaya california di Toserba Yogya dilihat dari aspek internal disebabkan karena pengalaman belajar dan memori dalam membeli buah pepaya california, dimana dimensi harga menjadi kendala. Berdasarkan tabel persentase frekuesi distribusi 5 dari 30 orang responden atau 16,70\% beranggapan harga buah pepaya california tidak sesuai, dan 23 dari 30 orang atau 76,70\% saat membeli buah pepaya california tidak ada potongan harga. Selain itu kendala lain dari aspek internal yaitu kepribadian dan konsep diri, $40 \%$ responden memiliki konsep dalam membeli buah pepaya california. Yang penting memiliki rasa buah pepaya california yang sama, responden tak perlu lagi membeli di pasar swalayan.

\section{b) Kendala Eksternal}

Kendala pada keputusan pembelian dilihat dari aspek eksternal disebabkan faktor sosial yaitu kelompok referensi dan keluarga. Sebagian kecil responden mengatakan bahwa mereka mendapat informasi melalui keluarga bahkan kerabat tentang referensi untuk membeli buah pepaya california yaitu di pasar tradisonal, dengan alasan harga yang lebih murah meskipun produk di bawah kualitas di Toserba Yogya Ciamis.

\section{KESIMPULAN DAN SARAN \\ Kesimpulan}

Berdasarkan hasil penelitian dan pembahasan maka dapat ditarik kesimpulan :

1. Tingkat persepsi konsumen dalam keputusan pembelian buah pepaya california di pasar swalayan yang dilakukan di Toserba Yogya Ciamis tergolong ke dalam kategori sedang. Tingkat persepsi jika dilihat per dimensi yaitu : a). Dimensi produk memiliki tingkat persepsi baik dengan persentase $100 \%$. b). Dimensi harga memiliki tingkat persepsi sedang dengan 
jumlah responden 25 orang dan persentase 83,33 \%. c). Dimensi promosi memiliki tingkat persepsi sedang dengan jumlah responden 23 orang dan persentase $76,67 \%$.

2. Kendala yang dihadapi dalam melakukan kegiatan pengambilan keputusan pembelian pepaya california di pasar swalayan yaitu :

a). Kendala internal ; pengalaman belajar dan memori dalam membeli buah pepaya california, dimana dimensi harga menjadi kendala. Selain itu kepribadian dan konsep diri, beberapa responden memiliki konsep dalam membeli buah pepaya california. Yang penting memiliki rasa buah pepaya california yang sama, responden tak perlu lagi membeli di pasar swalayan .

b) Kendala Eksternal ; faktor sosial yaitu kelompok referensi dan keluarga, perolehan informasi dan referensi tempat lain.

\section{Saran}

Berdasarkan kesimpulan tersebut, maka saran yang dapat diajukan kepada Toserba Yogya Ciamis adalah Tingkat persepsi dalam keputusan pembelian buah pepaya unuk dimensi harga dan promosi perlu ditingkatkan dengan penawaran potongan harga dan iklan yang menarik mengingat jika dihubungkan dengan kendala yang dihadapi, konsumen memiliki referensi lain untuk melakukan keputusan pembelian buah pepaya california.

\section{DAFTAR PUSTAKA}

Akdon dan Riduwan. 2001. Rumus dan Data untuk Penelitian( Administrasi pendidikan Bisnis Pemerintahan Sosial Kebijakan Ekonomi Hukum Manajemen). Alfabeta. Bandung.

Anjayani dan Haryanto. 2009. Geografi SMA XI. Cempaka Putih. Jakarta.

Azhari, D H. 2004. Dukungan Pengolahan dan Pemasaran Hasil Terhadap Pengembangan Agribisnis Hortikultura. Makalah Disampaikan Pada Pertemuan Sinkronisasi Pelaksanaan Pengembangan Hortikultura. Cisarua, Bogor.

Azizah, I. 2008. Analisis Pengaruh Persepsi dan Preferensi Konsumen Terhadap Keputusan Pembelian Buah Lokal ( Studi Pada Laila Market Buah Malang).Skripsi Jurusan Manajemen Fakultas Ekonomi Universitas Islam Negeri (UIN). Malang.

Buchory, A. H dan Saladin, D. 2010. Manajemen pemasaran Edisi Pertama. Linda Karya. Bandung.

Dharmmesta, S. B dan Handoko, H. T. 2008. Manajemen Pemasaran Analisis Perilaku Konsumen. BPFE-Yogyakarta. Yogyakarta.
Effendy, M. 2007. Manajemen Pemasaran. Fakultas Teknologi Pertanian Universitas Brawijaya. Malang.

Engel, F. J, Blackwell R D, Miniard P W. 2004. Perilaku Konsumen Terjemahan Alex Budianto Edisi Ke 6 Jilid 2. Bina Rupa Aksara. Jakarta.

Gita, D. 2005. Analisis Faktor-Faktor Yang Mempengaruhi Proses Keputusan Pembelian Pepaya Eksotik Dibandingkan Dengan Pepaya Lokal. Fakultas Pertanian. Institut Pertanian Bogor. Bogor.

Kotler, P. 2009. Manajemen Pemasaran Jilid 1 Edisi Milenium. Penerbit PT. Prehallindo. Jakarta.

2009. Manajemen Pemasaran Jilid 2 Edisi Milenium. Penerbit PT. Prehallindo. Jakarta.

Kotler, P dan Amstrong, G. 2012. Prinsip-prinsip Pemasaran Edisi 13 Jilid 1. Erlangga. Jakarta.

Kotler, P dan Keller. K. L. 2009. Manajemen Pemasaran Edisi 2. PT Indeks.Jakarta.

Mangkunegara, A.P.2009. Perilaku Konsumen Edisi Revisi Cetakan Keempat. PT. Refika Aditama. Bandung.

Nafisah, N. S., Suharno dan Tinaprilla. N. 2013. Sikap Dan Persepsi Konsumen Terhadap Jeruk Lokal Dan Jeruk Impor Di Pasar Modern Kota Bogor. Departemen Agribisnis, Fakultas Ekonomi dan Manajemen, Institut Pertanian Bogor. Bogor.

Nazir, M. 2011. Metode Penelitian.Ghalia Indonesia.Bogor.

Prasetijo, R dan Ihalauw. J. 2005. Perilaku Konsumen. Penerbit Andi. Jakarta.

Saharuddin, E. 2012. Kinerja Badan Kepegawaian Daerah Kabupaten Sidenreng Rappang. Skripsi Jurusan Ilmu Administrasi Fakultas Ilmu Sosial dan Ilmu Politik Universitas Hasanuddin. Makassar.

Schiffman dan Kanuk. 2008. Perilaku Konsumen (edisi 7). Rentice Hall. Jakarta.

Simamora. 2004. Riset Pemasaran. Gramedia Utama. Jakarta.

Sugiyono. 2012. Statistika Penelitian. CV ALFABETA. Bandung.

Suharno, Y S. 2010. Marketing In Practice. Graha Ilmu Yogyakarta Jurnal.Yogyakarta.

Susanti, T , Ratini R dan Mariyah. 2014. Analisis Pendapatan dan Pemasaran Usahatani Pepaya Mini ( Carica papaya L) Di Kelurahan Teritip Kecamatan Balikpapan Timur Kota Balikpapan. Jurnal AGRIFOR volume XIII nomor 1. Balikpapan.

Swastha, B dan Irawan. 2005. Manajemen Pemasaran Modern. Liberty. Yogyakarta.

Trimastuty, D, Kusnandar, Utami B W. 2013. Pengaruh Faktor Bauran Pemasaran Terhadap Keputusan Pembelian Buah Pepaya Califfornia 
Di Pasar Swalayan Kota Surakarta. E-Jurnal Agrista Edisi 4 Vol 1. Surakarta. 